Research Article

\title{
Experimental Study on the Temperature Field of Cold Region Tunnel under Various Groundwater Seepage Velocities
}

\author{
Shiding Cao $\mathbb{D},{ }^{1}$ Taishan Lu $\mathbb{D},,^{2,3}$ Bo Zheng $\mathbb{D}^{4}$, and Guozhu Zhang $\mathbb{D}^{2,3}$ \\ ${ }^{1}$ Shenzhen Transportation Design \& Research Institute Co., Ltd., Shenzhen 518000, China \\ ${ }^{2}$ Institute of Geotechnical Engineering, Southeast University, Nanjing 210096, China \\ ${ }^{3}$ Jiangsu Key Laboratory of Urban Underground Engineering \& Environmental Safety, Southeast University, \\ Nanjing 210096, China \\ ${ }^{4}$ Southwest Research Institute Co., Ltd of C. R. E. C., Chengdu, Sichuan 611731, China \\ Correspondence should be addressed to Taishan Lu; 230189653@seu.edu.cn
}

Received 16 October 2020; Revised 14 November 2020; Accepted 2 December 2020; Published 11 December 2020

Academic Editor: Zhi Cheng Tang

Copyright (C) 2020 Shiding Cao et al. This is an open access article distributed under the Creative Commons Attribution License, which permits unrestricted use, distribution, and reproduction in any medium, provided the original work is properly cited.

Groundwater seepage significantly affects the temperature field of a cold region tunnel. Laboratory model tests are carried out to evaluate its effects, yielding four main results. First, groundwater seepage can increase tunnel air temperature and decrease the thickness and length of the tunnel insulation layer. Second, groundwater seepage and tunnel ventilation exert a coupling effect on the surrounding rock temperature. This effect is related to the surrounding rock depth. Third, the influence of the groundwater seepage velocity on the temperature of the interface between the lining and surrounding rock demonstrates a spatial difference, and the groundwater seepage leads to an uneven temperature distribution at the interface between the lining and surrounding rock. Furthermore, under groundwater seepage, the shape and size of the tunnel cross section have significant effects on the interface temperature. Fourth, the cold region tunnel has an antifreezing capability that is mainly related to the frost heaving of the surrounding rock and the groundwater seepage velocity. This capability should be fully utilized in the design of cold region tunnels. The experimental data presented can be used to verify the reliability of the theoretical calculation model for tunnel temperatures in cold regions.

\section{Introduction}

Half of the world's land area is covered by transient permafrost, seasonal frozen soil, or permafrost [1, 2]. Cold region tunnels have been increasingly built in recent years but freezing damage to such tunnels threatens their structural and operational safety [3-6]. Aiming to solve the problem of freezing damage to cold region tunnels, investigations on their temperature field have increased. For example, Lai et al. [7] used dimensionless parameters and perturbation methods to approximate the temperature distribution of the surrounding rock of cold region tunnels. Zhang et al. [8] proposed an analytical solution for heat conduction in tunnels, considering both composite medium and time-dependent boundary conditions. Lai et al. [9] derived the governing equations for the coupled problems of seepage, temperature, and stress fields, with consideration of the ice-water phase change. Zhang et al. [10-12] derived an element calculation formula for the thermo-hydro coupling model to explore how different construction seasons, initial temperatures, and thermal insulation thicknesses affect the temperature field of cold region tunnels. Tan et al. [13-15] used the "three-zone" model to derive the governing equation for the temperature field of surrounding rock. The airflow inside the tunnel and the heat convection between the air and lining were simulated using the k-s turbulence model and the wall function. Li et al. [16] established a water-thermal coupling mathematical model for permafrost to determine the optimal thickness of the tunnel insulation layer. Yan et al. [17] performed a numerical investigation on the influences of different ventilation velocities on the design parameters of the thermal insulation layer. 
The above theoretical studies demonstrate the complexity of tunnel heat transfer in cold regions. Model tests can also be used to study the temperature field of the cold region tunnel. Feng et al. [18] developed a cold region tunnel model consisting of a refrigeration system, a circulation system, and a temperature control system with a $1: 25$ geometric reduced scale to study the temperature field and frost heave force of cold region tunnels and the reliability of thermal insulation layers. Zhang et al. [19] investigated the effects of the heat released during construction and of boundary temperatures on the temperature field of surrounding rock in permafrost tunnels using a model experiment with a $1: 26.83$ geometric reduced scale. Speeding up construction and installing insulation layers effectively weakened the negative effects of thermal disturbance during construction and of boundary temperatures. Zeng et al. [20] explored the influences of inlet airflow temperatures and mechanical ventilation on the temperature distribution of surrounding rock via a model test with a $1: 30$ geometric reduced scale under ventilation conditions. They found that mechanical ventilation in the positive ventilation direction adversely affects the freezing damage to cold region tunnels. Liu et al. [21] built a tunnel model with a $1: 37$ geometric reduced scale to explore the distribution of the temperature field and the expansion law of frost front under different inlet airflow temperatures and wind speeds.

Groundwater seepage has significant effects on the temperature field of the surrounding rock in cold region tunnels [9, 13, 22-24]. The frozen depth of cold region tunnels is significantly affected by the seepage velocity [9]. However, the above model tests did not consider its effects on the temperature field of cold region tunnels. In this paper, heat transfer model tests of cold region tunnels experiencing groundwater seepage are carried out. The model test results are used to analyze the distribution characteristics of the temperature field and to reveal the gradual freezing process of cold region tunnels under groundwater seepage. The results are also used to analyze the causes of freezing damage to cold region tunnels and to thereby provide a basis for its prevention and control.

\section{Model Test}

2.1. Investigating the Freezing Damage to a Prototype Tunnel. The freezing damage (shown in Figure 1) to two highway tunnels, one in the Inner Mongolia Autonomous Region and the other in Hebei Province, is investigated.

The highway tunnel from the Inner Mongolia Autonomous Region is a separated tunnel that is $3,960 \mathrm{~m}$ long on the left and 3,915 $\mathrm{m}$ long on the right, and the width of each tunnel is $12 \mathrm{~m}$. The average wind speed is $1.2 \mathrm{~m} / \mathrm{s}$, and the mean annual temperature is $-2.6^{\circ} \mathrm{C}$. The yearly frost-free period lasts for approximately 95 days. The frost penetration depth is $3 \mathrm{~m}$. The tunnel was opened to traffic in November 2012. In January 2013, the average temperature in was below $-25^{\circ} \mathrm{C}$, and a large number of leakages and extensive road ice occurred in the tunnel.
The highway tunnel from Hebei Province is a separated tunnel that is $2,946 \mathrm{~m}$ long on the left and $2,992 \mathrm{~m}$ long on the right, and the width of each tunnel is $12 \mathrm{~m}$. The average wind speed is $2.4 \mathrm{~m} / \mathrm{s}$, and the mean annual temperature is $3.2^{\circ} \mathrm{C}$. The yearly frost-free period lasts for approximately 120 days. The frost penetration depths of the entrance and exit of the tunnel are $1.4 \mathrm{~m}$ and $2 \mathrm{~m}$, respectively. In January 2016, the tunnel experienced extreme cold weather. The average temperature in January 2016 was close to $-25^{\circ} \mathrm{C}$. Freezing damage, such as leakage and water freezing, occurred in the tunnel.

Based on the freezing damage to two highway tunnels in the Inner Mongolia Autonomous Region and Hebei Province, a model test is conducted to investigate the distribution of the tunnel temperature field and the mechanism of freezing damage under various groundwater seepage velocities.

\subsection{Similarity Criteria for the Prototype and Model Tunnels.} The transient heat transfer in the concrete lining and surrounding rock of the tunnel prototype is governed by Fourier's law in the polar coordinates [25], as shown in the following equation:

$$
\frac{\partial T_{p}}{\partial t_{p}}=\alpha_{p}\left(\frac{\partial^{2} T_{p}}{\partial r_{p}^{2}}+\frac{1}{r_{p}} \frac{\partial T_{p}}{\partial r_{p}}\right), \quad r_{p}>\xi_{p},
$$

where subscript $p$ indicates the tunnel prototype, $T$ is the temperature, $r$ is the distance from the center of the tunnel, $t$ is the time, $\alpha$ is the thermal diffusivity, and $\xi$ is the inner radius of the tunnel lining.

The transient heat transfer in the concrete lining and surrounding rock of the tunnel model is governed by Fourier's law in the polar coordinates, as shown in the following equation:

$$
\frac{\partial T_{m}}{\partial t_{m}}=\alpha_{m}\left(\frac{\partial^{2} T_{m}}{\partial r_{m}^{2}}+\frac{1}{r_{m}} \frac{\partial T_{m}}{\partial r_{m}}\right), \quad r_{m}>\xi_{m},
$$

where subscript $m$ indicates the tunnel model.

According to similarity theory $[18,21]$, the heat transfer similarity criteria can be defined as follows:

$$
\begin{aligned}
& \pi_{1}=\frac{\alpha t}{r^{2}}, \\
& \pi_{2}=\frac{Q}{T C},
\end{aligned}
$$

where $\pi_{1}$ and $\pi_{2}$ are the heat transfer similarity criteria, $Q$ is the latent heat of the phase change due to groundwater freezing, and $C$ is determined as follows:

$$
c=\frac{\alpha}{\lambda}
$$

Based on equation (3), the following similarity relationships of temperature and time can be obtained: 


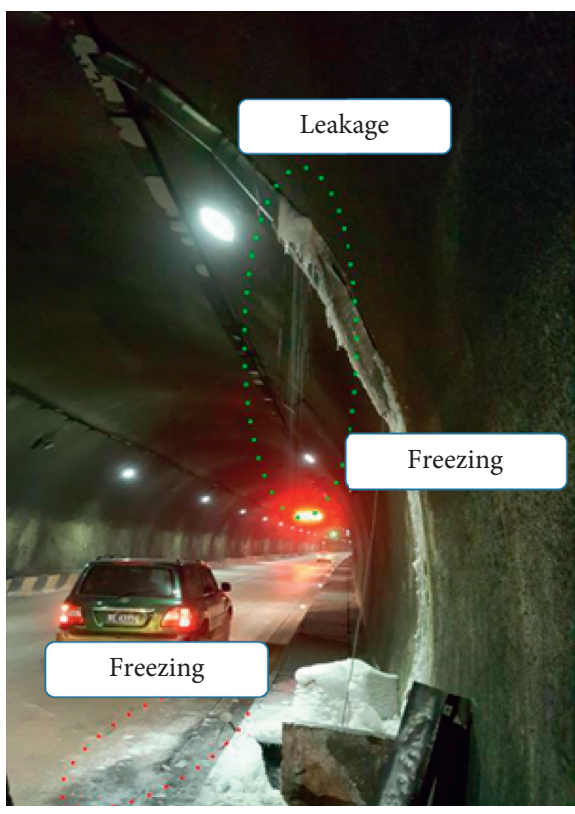

(a)

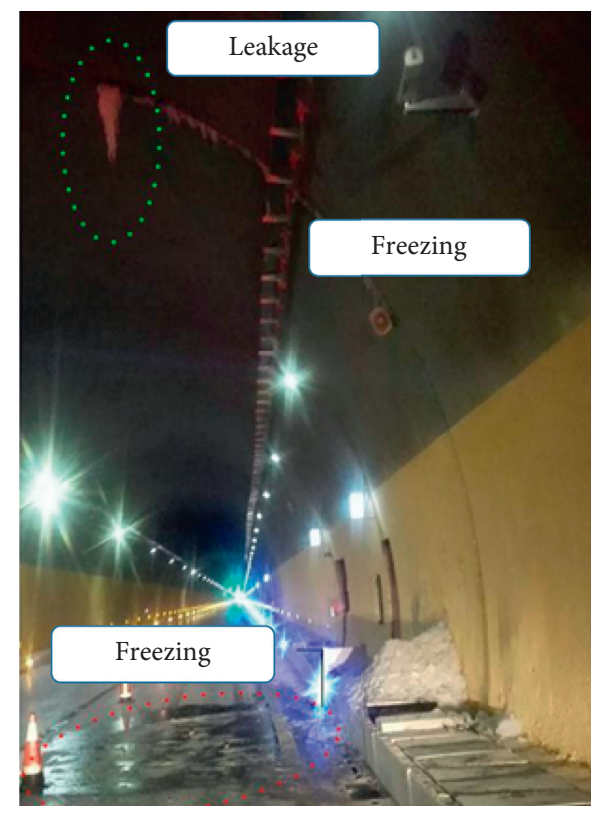

(b)

Figure 1: Freezing damage to tunnels in (a) the Inner Mongolia Autonomous Region and (b) Hebei Province.

$$
\begin{gathered}
\frac{T_{p}}{T_{m}}=\frac{Q_{p}}{Q_{m}} \frac{C_{m}}{C_{p}}, \\
\frac{t_{p}}{t_{m}}=\frac{\alpha_{m}}{\alpha_{p}} \frac{r_{p}^{2}}{r_{m}^{2}} .
\end{gathered}
$$

The groundwater seepage in the rock surrounding the tunnel can be modeled as a homogeneous flow in a medium with an effective porosity [26]. The groundwater seepage velocities of the tunnel prototype and tunnel model can be obtained using Darcy's law, as shown in the following equation, respectively:

$$
\begin{aligned}
& v_{p}=-K_{p} \frac{\partial u_{p}}{\partial r_{p}} \\
& v_{m}=-K_{m} \frac{\partial u_{m}}{\partial r_{m}}
\end{aligned}
$$

where $v$ is the groundwater seepage velocity, $u$ is the water head, and $K$ is the hydraulic conductivity.

The water head of the tunnel model is the same as that of the tunnel prototype. Based on equation (6), the following similarity relationship for groundwater seepage velocity can be obtained:

$$
\frac{v_{p}}{v_{m}}=\frac{K_{p}}{K_{m}} \frac{r_{m}}{r_{p}} .
$$

Considering the research results of previous tunnel heat transfer model tests $[16,18-21]$ and previous test conditions $[22,23]$, a geometric similarity ratio of $1: 30$ between the tunnel model and tunnel prototype is selected. According to equations (5) and (7), similarity ratios of 1:1,1:900, and 30:1 for temperature, time, and velocity, respectively, are obtained.
2.3. Model Test Design. Figure 2 describes the design of the cold region tunnel model test under the conditions of tunnel ventilation and groundwater seepage. In the model test, the fractured rock mass is considered to be a homogeneous medium with an effective porosity [26], the groundwater seepage in the tunnel surrounding rock is modeled as a homogeneous flow in a homogeneous medium with an effective porosity, and the sand soil is used to simulate the tunnel surrounding rock. Constant water head tests are used to simulate the groundwater seepage field of the tunnel surrounding rock, and water with a constant inlet temperature is used to simulate the underground temperature field. All of the tests have the same inlet temperature which is $13^{\circ} \mathrm{C}$. To ensure a uniform groundwater seepage field, groundwater seepage occurs from bottom to top. The groundwater seepage velocity is controlled by adjusting the water head difference. Cold airflow is blown into the tunnel through the closed circulation ventilation ducts to freeze the groundwater in the tunnel surrounding rock, and the wind speed variation is controlled by changing the voltage applied to the air blower. The temperatures of the surrounding rock, tunnel lining, and air in the tunnel are measured by temperature sensors. The wind speed is measured by using an ultrasonic anemometer, and the groundwater seepage velocity is measured by using a liquid mass flow meter.

2.4. Model Test Apparatus and Materials. Figure 3 presents the apparatus of the laboratory model test, which consists of the tunnel model box, the tunnel ventilation system, the groundwater seepage system, and the measuring system.

Table 1 summarizes the model test equipment and devices. 


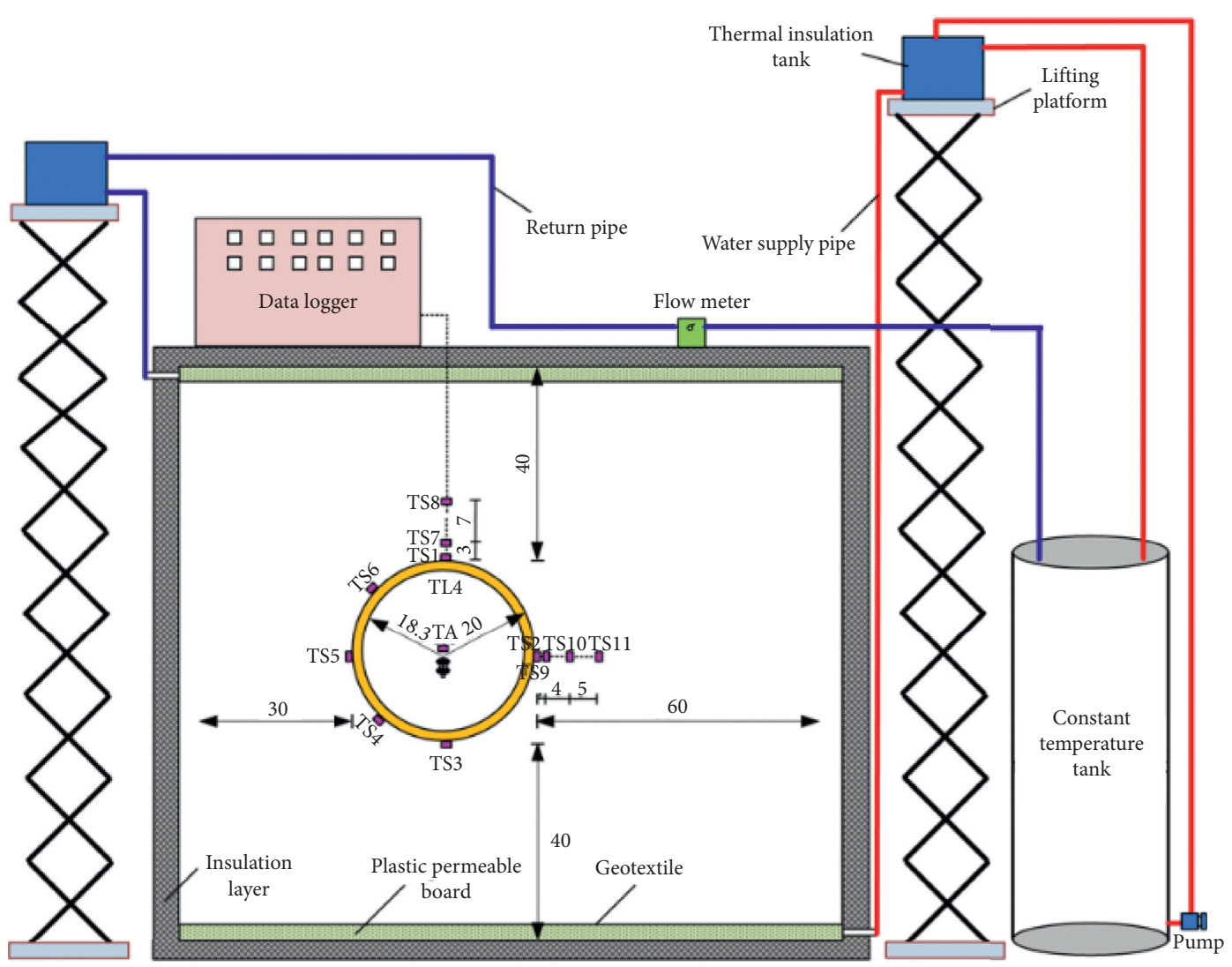

- Temperature sensor

* Ultrasonic anemometer

(a)

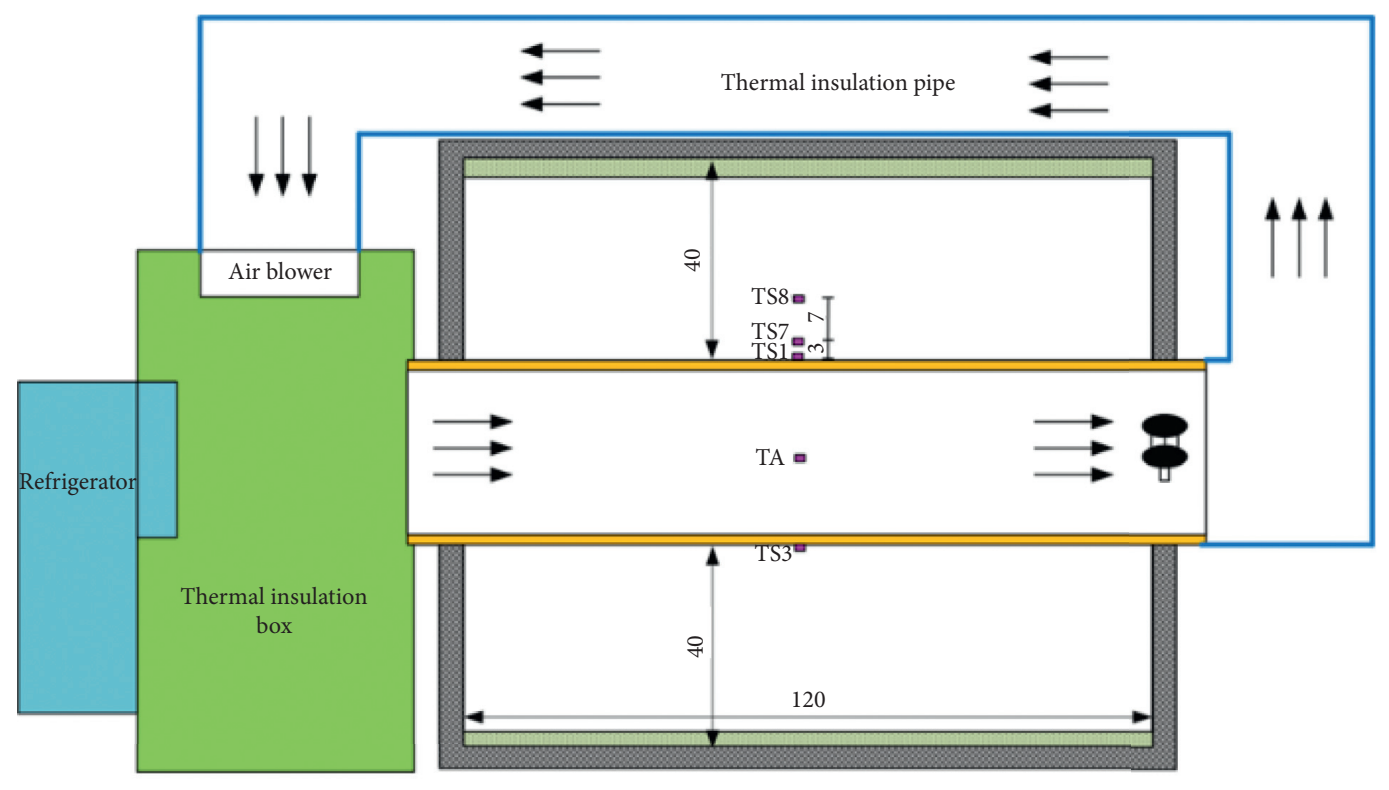

- Temperature sensor

* Ultrasonic anemometer

(b)

Figure 2: Model test design: (a) cross section and (b) vertical section. 


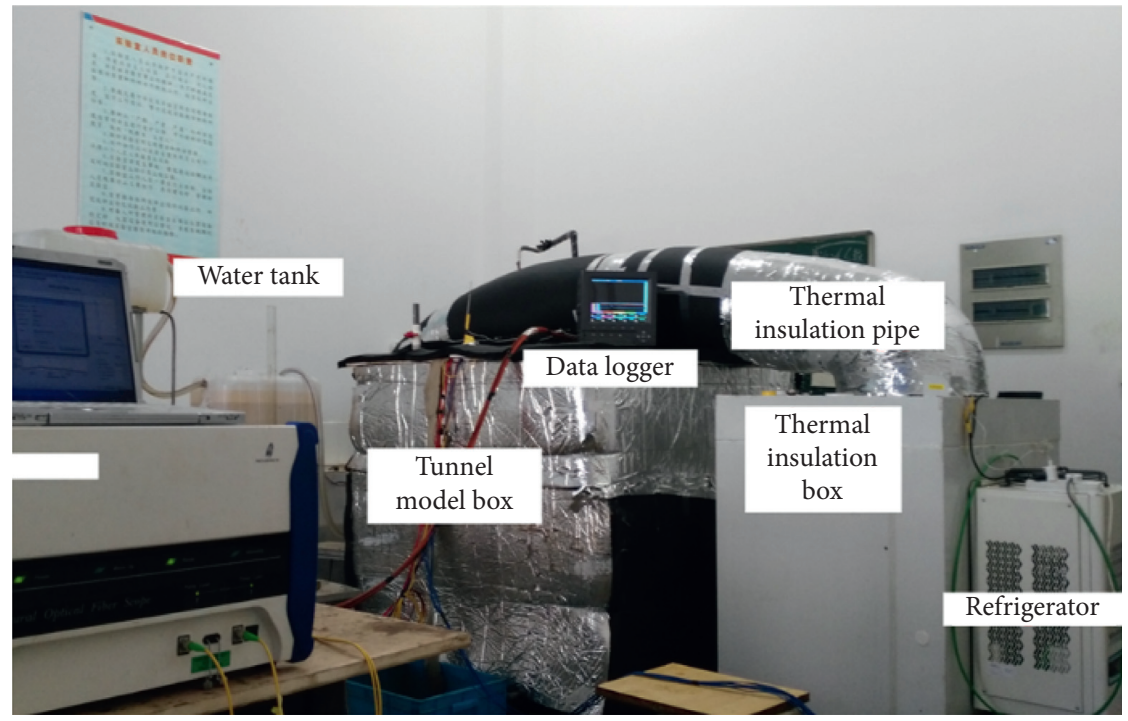

Figure 3: Model test setup.

TABLE 1: Model test equipment and devices.

\begin{tabular}{|c|c|}
\hline Item & Specification \\
\hline Constant temperature tank & Heating power is $6 \mathrm{~kW}$, volume is $1,000 \mathrm{~L}$ \\
\hline Pump & Water head is $9 \mathrm{~m}$, flow velocity is $30 \mathrm{~L} / \mathrm{min}$ \\
\hline Thermal insulation tank & Volume is $18 \mathrm{~L}$ \\
\hline Air blower & Maximum wind speed is $4 \mathrm{~m} / \mathrm{s}$ \\
\hline Temperature sensor & Resistance temperature detector (HSRTD-3-100-A) with an accuracy of $\pm 0.15^{\circ} \mathrm{C}$ \\
\hline Flow meter & Liquid mass flow meter (DMF-1-1-A) with a precision of $\pm 0.2 \%$, measurement scope is $0-40 \mathrm{~kg} / \mathrm{h}$ \\
\hline Ultrasonic anemometer & Measurement scope is $0-40 \mathrm{~m} / \mathrm{s}$, accuracy is $0.01 \mathrm{~m} / \mathrm{s}$ \\
\hline Refrigerator & Refrigerating power is $2 \mathrm{~kW}$, minimum temperature is $-30^{\circ} \mathrm{C}$ \\
\hline
\end{tabular}

2.4.1. Tunnel Model. The tunnel model consists of a $1.4 \mathrm{~m} \times 1.2 \mathrm{~m} \times 1.2 \mathrm{~m}$ stainless steel box and a $1.8 \mathrm{~m}$ concrete tube with an outer diameter of $40 \mathrm{~cm}$ and a thickness of $2 \mathrm{~cm}$. The concrete tube, which has a circular cross section, is made of cement, sand, gravel, and water in a ratio of $1: 2.4: 3.6: 0.65$. Sand is used in the test. The sand-raining method is used to fill the tunnel model with sand from the Yangtze River, the density and thermal conductivities of which are $2.05 \mathrm{~g} / \mathrm{cm}^{3}$ and $1.58 \mathrm{~W} /\left(\mathrm{m} \cdot{ }^{\circ} \mathrm{C}\right)$, respectively. To minimize the heat transfer boundary effect, a $5-\mathrm{cm}$ thick thermal insulation layer is installed around the outer surface of the stainless steel box. The plastic permeable boards are installed at the top and bottom of the stainless steel box to ensure that the groundwater seepage spreads over the surrounding rock. The permeable plastic boards are wrapped with geotextile to prevent the groundwater seepage from carrying away the sand.

2.4.2. Tunnel Ventilation System. The ventilation system consists of a refrigerator, an air blower, a thermal insulation box, and a thermal insulation pipe. The thermal insulation pipe connects the air blower, the thermal insulation box, and the concrete tube to form closed circulation ventilation ducts. The air blower is installed on the top of the thermal insulation box, and the refrigerator is installed in the thermal insulation box. The air inside the refrigerator can be cooled to $-30^{\circ} \mathrm{C}$, and the airflow velocity in the ducts can reach $4 \mathrm{~m} / \mathrm{s}$.
2.4.3. Groundwater Seepage System. The groundwater seepage system consists of a constant temperature water tank, a pump, two thermal insulation water tanks, two lifting platforms, a water supply pipe, and a return pipe. The water supply pipe and return pipe connect the constant temperature water tank, the pump, the thermal insulation water tanks, and the stainless steel box to form a closed circulation system. Both thermal insulation water tanks are placed on the lifting platforms. The groundwater seepage velocity is controlled by adjusting the height difference between the two thermal insulation water tanks.

2.4.4. Measuring System. To monitor the temperature variations in the air, surrounding rock, and the interface between the tunnel lining and surrounding rock, a temperature monitoring cross section is installed in the middle of the model box. The platinum resistance temperature sensor TA is installed in the center of the concrete tube to monitor the temperature of the airflow. The platinum resistance temperature sensors TS7 to TS11 are installed in the sand to monitor the temperature variation of the surrounding rock temperature field at different positions and depths. The platinum resistance temperature sensors TS1 to TS6 are installed on the concrete tube surface, equally spaced along the cross section, to monitor the temperature variation of the interface between the tunnel lining and surrounding rock. 
The wind speed is monitored using an ultrasonic anemometer that is placed at the tunnel exit. Finally, the liquid mass flow meter is connected to the water return pipe of the groundwater seepage system.

2.5. Model Test Strategy. Two factors are considered in the model test, namely, wind speed and groundwater seepage velocity. Zhang et al. [22] presented a systematic study of the heat transfer in tunnels under groundwater seepage. Groundwater seepage velocities of less than $0.864 \mathrm{~m} / \mathrm{d}$ had negligible effects on the temperature field of the surrounding rock. Thus, groundwater seepage velocities of $0,0.923$ and $2.743 \mathrm{~m} / \mathrm{d}$ are chosen for this model. The average wind speed of the tunnel in the Inner Mongolia Autonomous Region and in Hebei Province is $2.2 \mathrm{~m} / \mathrm{s}$ and $2.4 \mathrm{~m} / \mathrm{s}$, respectively. Thus, wind speeds of $0.606,1.002$, and $2.398 \mathrm{~m} / \mathrm{s}$ are chosen for this model. Table 2 presents the model test strategy. The experiment time of each test is different, as groundwater seepage can prevent the surrounding rock from freezing. Hence, the time that the temperature of surrounding rock down to $0^{\circ} \mathrm{C}$ varies with groundwater seepage velocities. The experiment times of $11.5,23$, and $32.5 \mathrm{~h}$ for groundwater seepage velocities of $0,0.923$, and $2.743 \mathrm{~m} / \mathrm{d}$, respectively, are chosen for this model. These experiment times can guarantee a part of the surrounding rock around the lining will freeze.

\section{Results and Discussion}

3.1. Effect of Groundwater Seepage on the Tunnel Air Temperature. Figure 4 presents the variations in tunnel air temperature over time under the effects of groundwater seepage and ventilation in the model test. Specifically, it shows that the air temperature in the tunnel decreases. Furthermore, the air temperature reduction rate decreases over time, and the temperature curve fluctuates every $12 \mathrm{~h}$ due to the deicing of the refrigeration equipment. Figure 4 also shows that groundwater seepage velocity and wind speed have significant influences on tunnel air temperature. Figure 5 presents the variations in tunnel air temperature for various groundwater seepage velocities at different wind speeds after cooling for $11.5 \mathrm{~h}$. In Figure 5, the air temperature in the tunnel increases almost linearly as the groundwater seepage velocity increases. Furthermore, the effect of groundwater seepage velocity on air temperature in the tunnel is related to wind speed. The lowest air temperature in the tunnel is $-22.55^{\circ} \mathrm{C}$ under a groundwater seepage velocity of $0 \mathrm{~m} / \mathrm{s}$ and a wind speed of $0.606 \mathrm{~m} / \mathrm{s}$. The highest air temperature in the tunnel is $-14.58^{\circ} \mathrm{C}$ under a groundwater seepage velocity of $2.743 \mathrm{~m} / \mathrm{d}$ and a wind speed of $2.398 \mathrm{~m} / \mathrm{s}$. Thus, the higher the groundwater seepage velocity and wind speed are, the higher the air temperature is in the tunnel.

The above analysis shows that groundwater seepage has a significant effect on the air temperature in a tunnel. The higher the groundwater seepage velocity is, the higher the air temperature is in the tunnel. Low air temperature in a tunnel may induce tunnel freezing damage. The thickness and length of the tunnel insulation layer are determined by the
TABLE 2: Model test strategy.

\begin{tabular}{lcc}
\hline Test no. Groundwater seepage velocity $(\mathrm{m} / \mathrm{d})$ & Wind speed $(\mathrm{m} / \mathrm{s})$ \\
\hline 1 & & 0.606 \\
2 & 0 & 1.002 \\
3 & & 2.398 \\
\hline 4 & 0.923 & 0.606 \\
5 & & 1.002 \\
6 & & 2.398 \\
\hline 7 & 2.743 & 0.606 \\
8 & & 1.002 \\
9 & & 2.398 \\
\hline
\end{tabular}

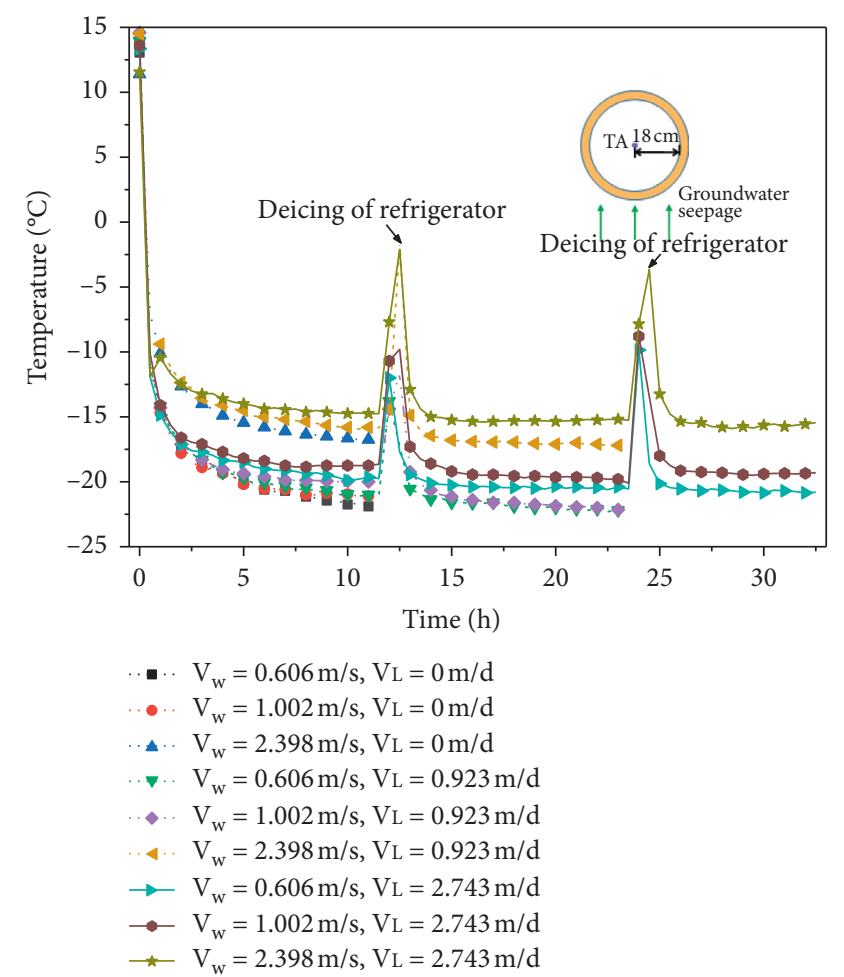

FIgURE 4: Variations in the tunnel air temperature over time.

air temperature in the tunnel. Specifically, the lower the air temperature is in the tunnel, the thicker and longer the tunnel insulation layer needs to be to avoid freezing damage. It can be speculated that groundwater seepage has a significant influence on the thickness and length of the tunnel insulation layer in cold regions, causing it to thin and short. Thus, the influence of groundwater seepage should be considered when designing the insulation layers of cold region tunnels.

3.2. Effect of Groundwater Seepage on the Surrounding Rock Temperature. Figure 6 presents the variations in the surrounding rock temperature over time under the influence of groundwater seepage and ventilation in the model test. Specifically, it shows that the surrounding rock temperature at TS9, TS10, and TS11 decreases. The cooling rates and amplitudes of the surrounding rock temperature differ significantly between TS9, TS10, and TS11. The cooling rate 


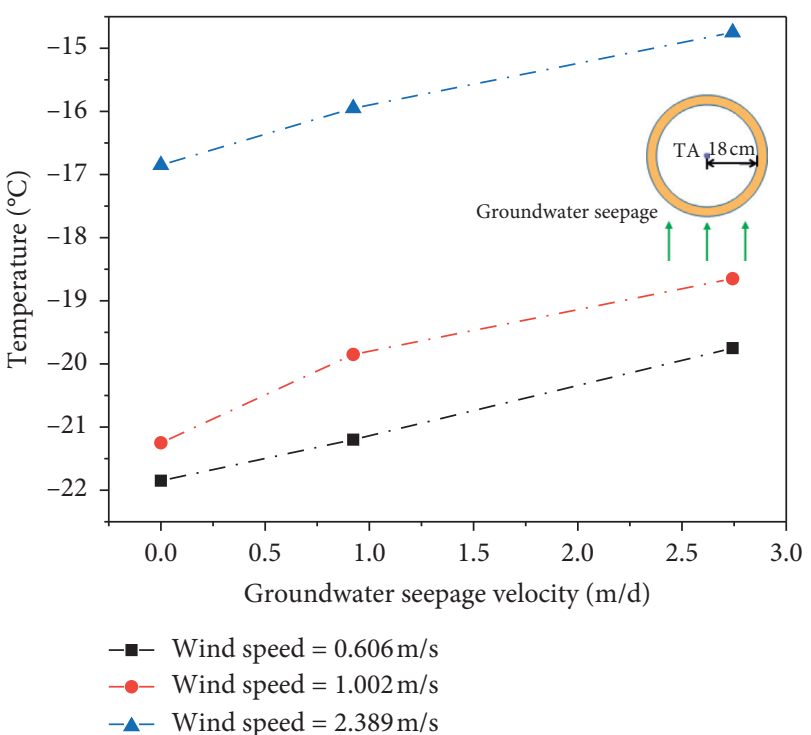

FIgURE 5: Variations in the tunnel air temperature after $11.5 \mathrm{~h}$ of cooling.

and amplitude of the surrounding rock temperature are related to the depth of the tunnel surrounding rock, the groundwater seepage velocity, and the wind speed. The cooling rate and amplitude of the surrounding rock temperature at the TS9 monitoring point are the largest and those at the TS11 monitoring point are the smallest. Thus, the deeper the tunnel surrounding rock is, the lower the cooling rate and amplitude of the tunnel surrounding rock temperature are. Lower groundwater seepage velocities and higher wind speeds lead to greater cooling rates and amplitudes of the surrounding rock temperature. The influence of groundwater seepage and tunnel ventilation on the surrounding rock temperature field is related to the depth of the surrounding rock. The increase in wind speed has a strong influence on the temperature field at TS9 and TS10 but a weak influence on that at TS11. Figure 6 also shows that the wind speed has the most significant influence on the surrounding rock temperature field when the groundwater seepage velocity is $0.923 \mathrm{~m} / \mathrm{d}$ but has the least significant influence on the surrounding rock temperature field when the groundwater seepage velocity is $0 \mathrm{~m} / \mathrm{d}$. This can be explained by the coupling effect of groundwater seepage and tunnel ventilation.

Figure 7 presents the variations in the surrounding rock temperature drops under groundwater seepage velocities at different wind speeds after $11.5 \mathrm{~h}$ of cooling. It also shows that the temperature drops in the tunnel surrounding rock decrease as the groundwater seepage velocity increases. The temperature drops differ at TS9, TS10, and TS11 under different wind speeds. The temperature drop at TS11 at different wind speeds decreases linearly as the groundwater seepage velocity increases. At wind speeds of $0.606 \mathrm{~m} / \mathrm{s}$ and $1.002 \mathrm{~m} / \mathrm{s}$, the temperature drops at TS9 and TS10 decrease linearly as the groundwater seepage velocity increases. At a wind speed of $2.398 \mathrm{~m} / \mathrm{s}$ and groundwater seepage velocity under $0.923 \mathrm{~m} / \mathrm{d}$, the temperature drops at TS9 and TS10 slowly decrease as the groundwater seepage velocity increases. At a wind speed of $2.398 \mathrm{~m} / \mathrm{s}$ and groundwater seepage velocity over $0.923 \mathrm{~m} / \mathrm{d}$, the temperature drops at TS9 and TS10 sharply decrease as the groundwater seepage velocity increases.

The above analysis shows that groundwater seepage and tunnel ventilation have a coupling effect on the surrounding rock temperature. Specifically, higher groundwater seepage velocities and lower wind speeds lead to higher surrounding rock temperatures. Thus, the coupling influence of groundwater seepage and tunnel ventilation should be considered when designing the insulation layers of cold region tunnels.

\subsection{Effect of Groundwater Seepage on the Temperature at the} Interface between the Lining and Surrounding Rock. Figure 8 presents the temperature variation over time at the interface between the lining and surrounding rock under the influence of groundwater seepage and ventilation in the model test. It shows that the interface temperatures of TS1, TS3, TS4, TS5, and TS6 decrease over time when groundwater seepage and ventilation are considered in the model test. Groundwater seepage has a significant effect on the interface temperature. The effect is related to the location of the monitoring points. Therefore, the cooling rates and amplitudes of the interface temperature for TS1, TS3, TS4, TS5, and TS6 differ significantly. The groundwater seepage has the most significant effects on measuring points TS3 and TS4 and has the least significant effects on measuring points TS1 and TS6. Wind speed also has a significant effect on the interface temperature. The effect is related to the groundwater seepage velocity. These results indicate that groundwater seepage and tunnel ventilation have a coupling effect on the interface temperature and that this coupling effect is related to the interface location.

Figure 9 shows the variations in the temperature drops at TS1, TS3, TS4, TS5, and TS6 with groundwater seepage velocity under tunnel ventilation after $11.5 \mathrm{~h}$ of cooling. It shows that the temperature drops at TS3 and TS4 upstream of the groundwater seepage field decrease as the groundwater seepage velocity increases. However, the temperature drops at TS1 and TS6 downstream of the groundwater seepage field increase as the groundwater seepage velocity increases from 0 to $0.923 \mathrm{~m} / \mathrm{d}$. Furthermore, the temperature drops at TS1 and TS6 decrease as the groundwater seepage velocity increases from 0.923 to $2.743 \mathrm{~m} / \mathrm{d}$. The smallest temperature drop occurs at TS3 (upstream of the groundwater seepage field), and the largest temperature drop occurs at TS1 (downstream of the groundwater seepage field) under groundwater seepage. These results indicate that groundwater seepage leads to an uneven temperature distribution at the interface between the lining and surrounding rock and that tunnel ventilation enhances this uneven distribution.

Figure 10 presents the temperature differences between TS3, TS5, and TS6. The temperature at TS3 is higher under groundwater seepage than those at TS5 and TS6. The interface temperature upstream of the groundwater field is higher than that downstream. Figure 10 also shows that the temperature difference between TS3 and TS6 increases as the groundwater 

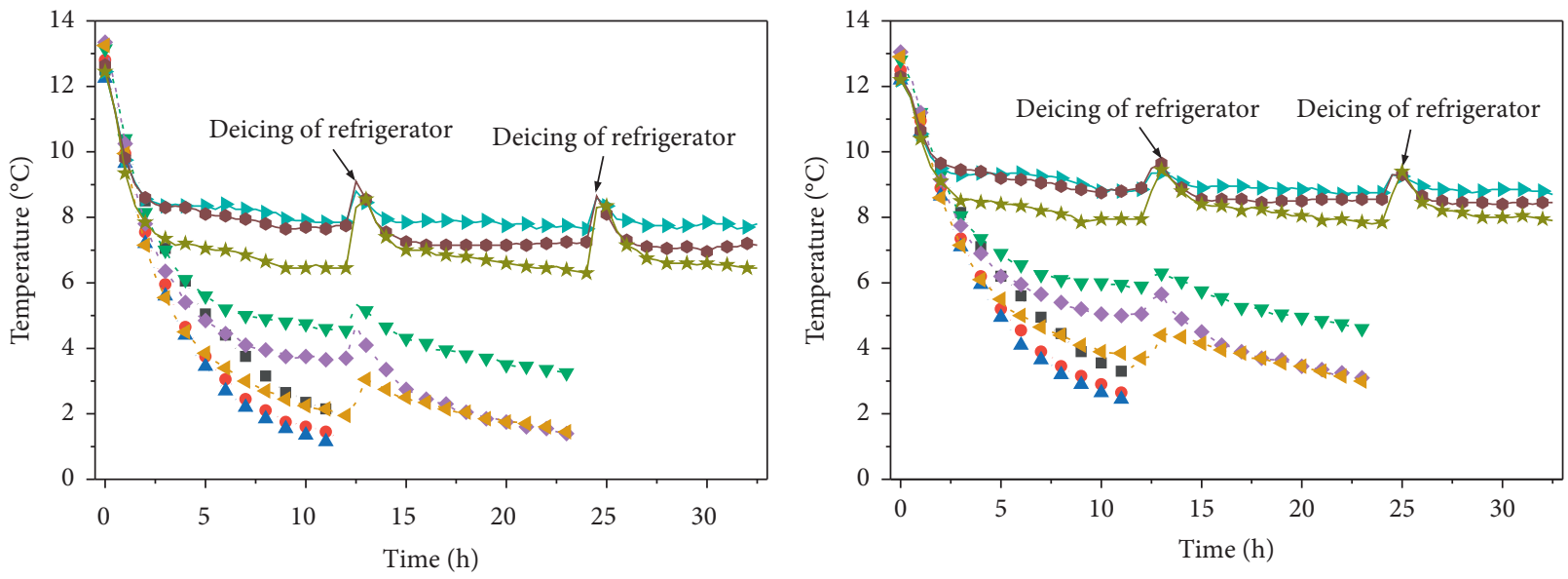

- ․ $\mathrm{V}_{\mathrm{w}}=0.606 \mathrm{~m} / \mathrm{s}, \mathrm{VL}_{\mathrm{L}}=0 \mathrm{~m} / \mathrm{d}$

-. $\mathrm{V}_{\mathrm{w}}=1.002 \mathrm{~m} / \mathrm{s}, \mathrm{VL}_{\mathrm{L}}=0 \mathrm{~m} / \mathrm{d}$

A. $\mathrm{V}_{\mathrm{w}}=2.398 \mathrm{~m} / \mathrm{s}, \mathrm{VL}_{\mathrm{L}}=0 \mathrm{~m} / \mathrm{d}$

?. $\mathrm{V}_{\mathrm{w}}=0.606 \mathrm{~m} / \mathrm{s}, \mathrm{VL}_{\mathrm{L}}=0.923 \mathrm{~m} / \mathrm{d}$

- $\mathrm{V}_{\mathrm{w}}=1.002 \mathrm{~m} / \mathrm{s}, \mathrm{VL}_{\mathrm{L}}=0.923 \mathrm{~m} / \mathrm{d}$

4. $\mathrm{V}_{\mathrm{w}}=2.398 \mathrm{~m} / \mathrm{s}, \mathrm{VL}_{\mathrm{L}}=0.923 \mathrm{~m} / \mathrm{d}$

$\rightarrow \mathrm{V}_{\mathrm{w}}=0.606 \mathrm{~m} / \mathrm{s}, \mathrm{VL}=2.743 \mathrm{~m} / \mathrm{d}$

$\because \mathrm{V}_{\mathrm{w}}=1.002 \mathrm{~m} / \mathrm{s}, \mathrm{VL}=2.743 \mathrm{~m} / \mathrm{d}$

* $\mathrm{V}_{\mathrm{w}}=2.398 \mathrm{~m} / \mathrm{s}, \mathrm{VL}=2.743 \mathrm{~m} / \mathrm{d}$

- . $V_{\mathrm{w}}=0.606 \mathrm{~m} / \mathrm{s}, \mathrm{VL}=0 \mathrm{~m} / \mathrm{d}$

-. $\mathrm{V}_{\mathrm{w}}=1.002 \mathrm{~m} / \mathrm{s}, \mathrm{VL}=0 \mathrm{~m} / \mathrm{d}$

A. $V_{\mathrm{w}}=2.398 \mathrm{~m} / \mathrm{s}, \mathrm{VL}_{\mathrm{L}}=0 \mathrm{~m} / \mathrm{d}$

*. $V_{\mathrm{w}}=0.606 \mathrm{~m} / \mathrm{s}, \mathrm{V}_{\mathrm{L}}=0.923 \mathrm{~m} / \mathrm{d}$

- $\mathrm{V}_{\mathrm{w}}=1.002 \mathrm{~m} / \mathrm{s}, \mathrm{VL}_{\mathrm{L}}=0.923 \mathrm{~m} / \mathrm{d}$

4. $V_{\mathrm{w}}=2.398 \mathrm{~m} / \mathrm{s}, \mathrm{VL}_{\mathrm{L}}=0.923 \mathrm{~m} / \mathrm{d}$

$\rightarrow \mathrm{V}_{\mathrm{w}}=0.606 \mathrm{~m} / \mathrm{s}, \mathrm{VL}=2.743 \mathrm{~m} / \mathrm{d}$

$\longrightarrow \mathrm{V}_{\mathrm{w}}=1.002 \mathrm{~m} / \mathrm{s}, \mathrm{VL}_{\mathrm{L}}=2.743 \mathrm{~m} / \mathrm{d}$

* $\mathrm{V}_{\mathrm{w}}=2.398 \mathrm{~m} / \mathrm{s}, \mathrm{VL}_{\mathrm{L}}=2.743 \mathrm{~m} / \mathrm{d}$

(a)

(b)

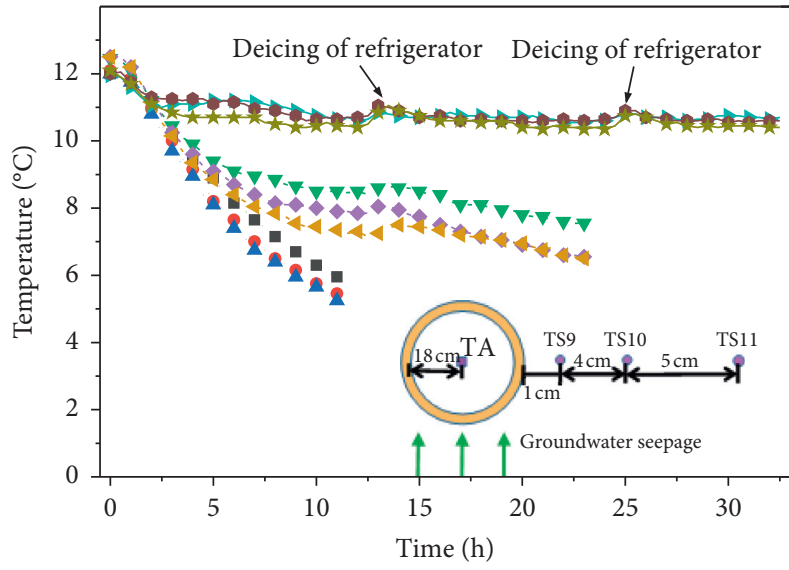

$\therefore \mathrm{V}_{\mathrm{w}}=0.606 \mathrm{~m} / \mathrm{s}, \mathrm{VL}=0 \mathrm{~m} / \mathrm{d}$

- $\mathrm{V}_{\mathrm{w}}=1.002 \mathrm{~m} / \mathrm{s}, \mathrm{VL}_{\mathrm{L}}=0 \mathrm{~m} / \mathrm{d}$

... $V_{\mathrm{w}}=2.398 \mathrm{~m} / \mathrm{s}, \mathrm{VL}=0 \mathrm{~m} / \mathrm{d}$

V. $V_{\mathrm{w}}=0.606 \mathrm{~m} / \mathrm{s}, \mathrm{VL}=0.923 \mathrm{~m} / \mathrm{d}$

… $\mathrm{V}_{\mathrm{w}}=1.002 \mathrm{~m} / \mathrm{s}, \mathrm{VL}=0.923 \mathrm{~m} / \mathrm{d}$

4. $V_{\mathrm{w}}=2.398 \mathrm{~m} / \mathrm{s}, \mathrm{VL}_{\mathrm{L}}=0.923 \mathrm{~m} / \mathrm{d}$

$\rightarrow \quad V_{\mathrm{w}}=0.606 \mathrm{~m} / \mathrm{s}, \mathrm{VL}_{\mathrm{L}}=2.743 \mathrm{~m} / \mathrm{d}$

$\rightarrow \mathrm{V}_{\mathrm{w}}=1.002 \mathrm{~m} / \mathrm{s}, \mathrm{VL}_{\mathrm{L}}=2.743 \mathrm{~m} / \mathrm{d}$

\# $\mathrm{V}_{\mathrm{w}}=2.398 \mathrm{~m} / \mathrm{s}, \mathrm{VL}=2.743 \mathrm{~m} / \mathrm{d}$

(c)

FIGURE 6: Variations in the surrounding rock temperature over time. 

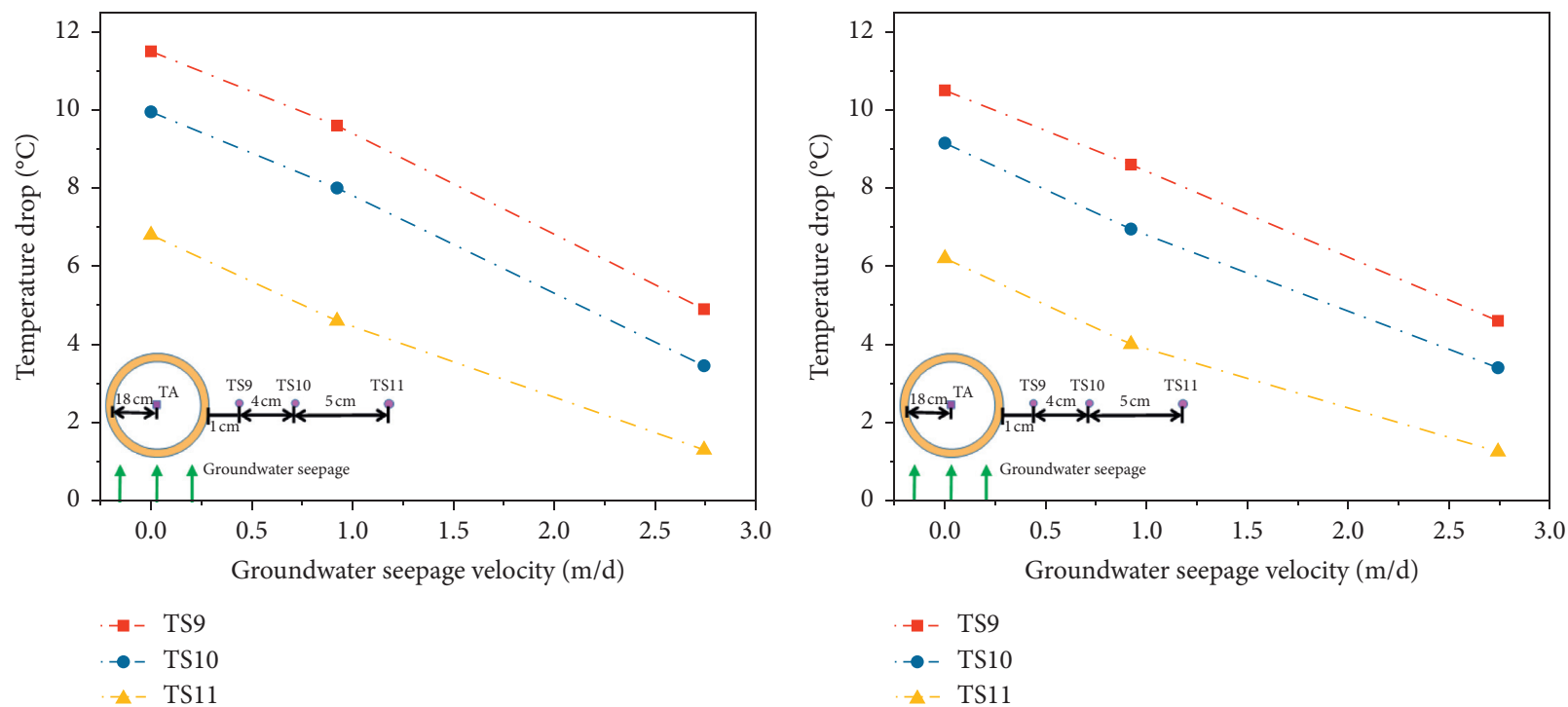

(a)

(b)

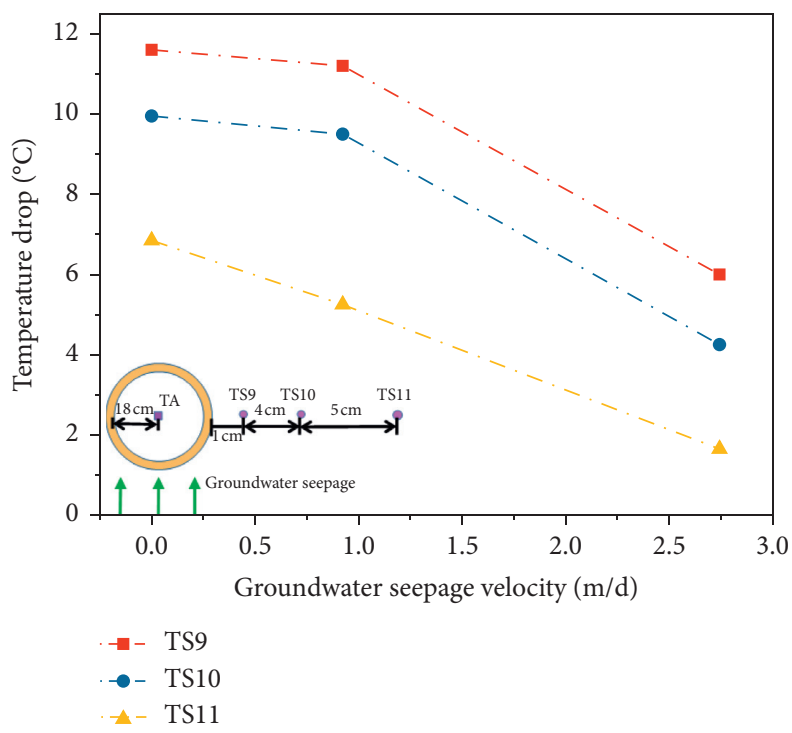

(c)

FIGURE 7: Variations in the surrounding rock temperature drop at different groundwater seepage velocities after $11.5 \mathrm{~h}$ of cooling. Average wind speed of (a) $0.606 \mathrm{~m} / \mathrm{s}$, (b) $1.002 \mathrm{~m} / \mathrm{s}$, and (c) $2.398 \mathrm{~m} / \mathrm{s}$.

seepage velocity increases. Thus, the higher the groundwater seepage velocity is, the higher the temperature difference is between TS3 and TS6. The temperature difference between TS3 and TS5 increases as the groundwater seepage velocity increases from 0 to $0.923 \mathrm{~m} / \mathrm{d}$ and decreases as the groundwater seepage velocity increases from 0.923 to $2.743 \mathrm{~m} / \mathrm{d}$. Groundwater seepage has a great effect on the interface temperature. This effect has a spatial difference. Thus, both the shape and size of the cross section of the tunnel significantly affect the interface temperature under groundwater seepage.

3.4. Effect of Groundwater Seepage on the Freezing Damage to Cold Region Tunnels. The tunnel drainage system is located between the lining and the surrounding rock.
Monitoring points TS3, TS5, and TS6 are located at the top, middle, and foot of the tunnel drainage system, respectively. The temperatures at TS3, TS5, and TS6 determine the antifreezing ability of cold region tunnels. Therefore, the higher the temperatures at TS3, TS5, and TS6 are, the stronger the antifreezing capability of the tunnel in cold regions is. Figure 8 shows that when the groundwater seepage velocity is $0 \mathrm{~m} / \mathrm{d}$, the measuring points TS3, TS5, and TS6 freeze synchronously. If the tunnel surrounding rock is free of frost heaving, cold region tunnels may not need a thermal insulation layer. When the groundwater seepage velocity is $0.923 \mathrm{~m} / \mathrm{d}$, the monitoring point TS6 freezes first. The interface then gradually freezes from TS6 to TS5 along the circumferential direction of the tunnel section. This explains why 

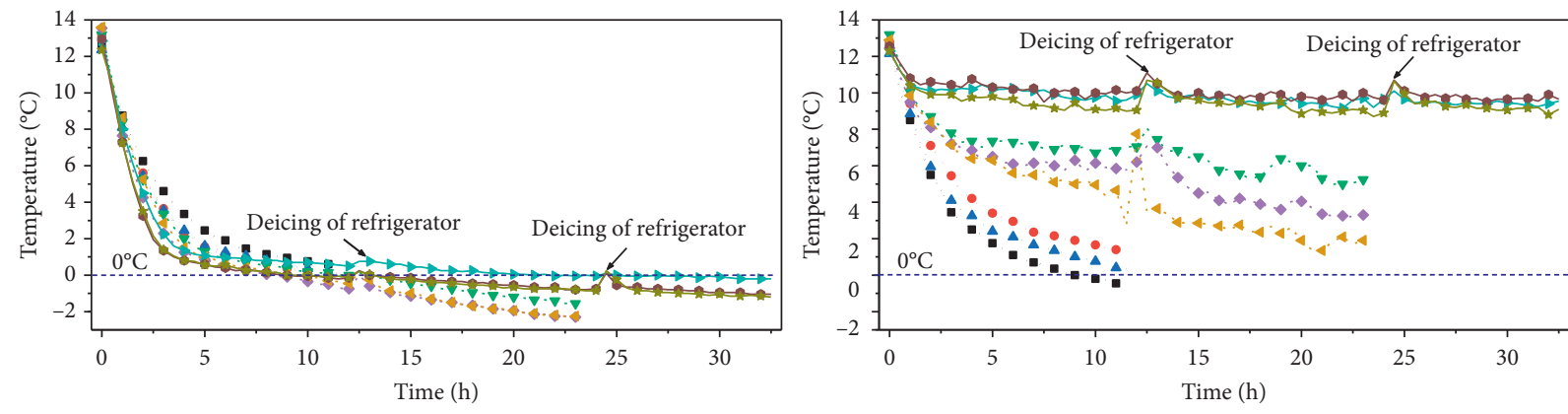

$\ldots \mathrm{V}_{\mathrm{w}}=0.606 \mathrm{~m} / \mathrm{s}, \mathrm{V}_{\mathrm{L}}=0 \mathrm{~m} / \mathrm{d}$

-. $\mathrm{V}_{\mathrm{w}}=1.002 \mathrm{~m} / \mathrm{s}, \mathrm{V}_{\mathrm{L}}=0 \mathrm{~m} / \mathrm{d}$

-. $\mathrm{V}_{\mathrm{w}}=2.398 \mathrm{~m} / \mathrm{s}, \mathrm{V}_{\mathrm{L}}=0 \mathrm{~m} / \mathrm{d}$

$\ldots \mathrm{V}_{\mathrm{w}}=0.606 \mathrm{~m} / \mathrm{s}, \mathrm{V}_{\mathrm{L}}=0.923 \mathrm{~m} / \mathrm{d}$

-.. $\mathrm{V}_{\mathrm{w}}=1.002 \mathrm{~m} / \mathrm{s}, \mathrm{V}_{\mathrm{L}}=0.923 \mathrm{~m} / \mathrm{d}$

4. $\mathrm{V}_{\mathrm{w}}=2.398 \mathrm{~m} / \mathrm{s}, \mathrm{V}_{\mathrm{L}}=0.923 \mathrm{~m} / \mathrm{d}$

$\rightarrow-V_{w}=0.606 \mathrm{~m} / \mathrm{s}, V_{\mathrm{L}}=2.743 \mathrm{~m} / \mathrm{d}$

$\multimap \mathrm{V}_{\mathrm{w}}=1.002 \mathrm{~m} / \mathrm{s}, \mathrm{V}_{\mathrm{L}}=2.743 \mathrm{~m} / \mathrm{d}$

\# $\mathrm{V}_{\mathrm{w}}=2.398 \mathrm{~m} / \mathrm{s}, \mathrm{V}_{\mathrm{L}}=2.743 \mathrm{~m} / \mathrm{d}$

(a)

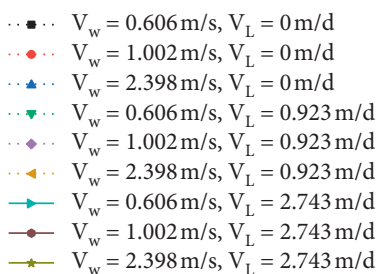

(b)
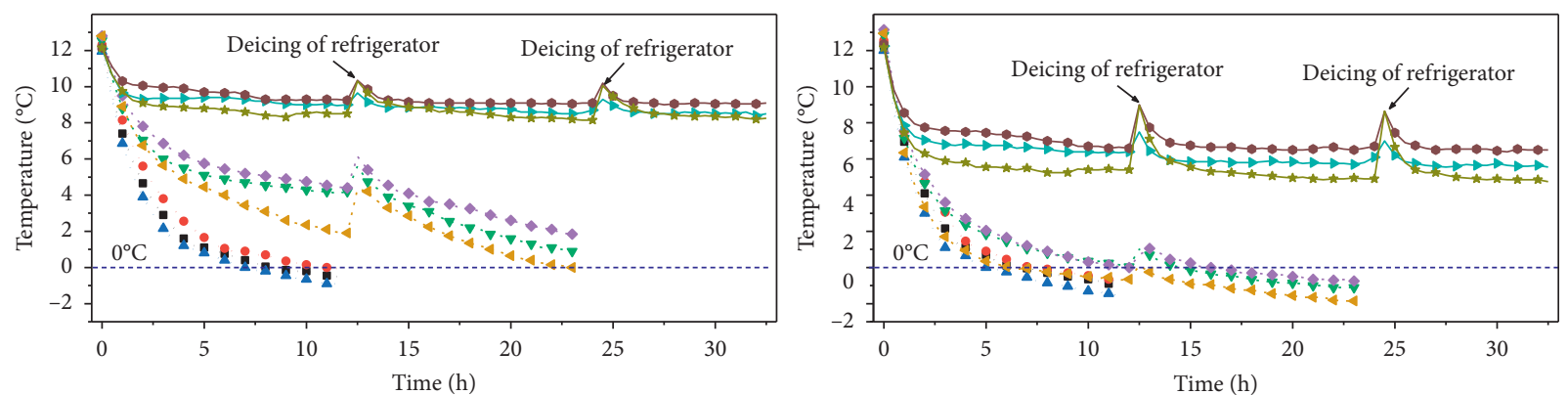

- $\cdot \mathrm{V}_{\mathrm{w}}=0.606 \mathrm{~m} / \mathrm{s}, \mathrm{V}_{\mathrm{L}}=0 \mathrm{~m} / \mathrm{d}$

… $\mathrm{V}_{\mathrm{w}}=1.002 \mathrm{~m} / \mathrm{s}, \mathrm{V}_{\mathrm{L}}=0 \mathrm{~m} / \mathrm{d}$

‥ $V_{w}=2.398 \mathrm{~m} / \mathrm{s}, \mathrm{V}_{\mathrm{L}}=0 \mathrm{~m} / \mathrm{d}$

$\because \mathrm{V}_{\mathrm{w}}=0.606 \mathrm{~m} / \mathrm{s}, \mathrm{V}_{\mathrm{L}}=0.923 \mathrm{~m} / \mathrm{d}$

-.. $\mathrm{V}_{\mathrm{w}}=1.002 \mathrm{~m} / \mathrm{s}, \mathrm{V}_{\mathrm{L}}=0.923 \mathrm{~m} / \mathrm{d}$

… $V_{w}=2.398 \mathrm{~m} / \mathrm{s}, V_{\mathrm{L}}=0.923 \mathrm{~m} / \mathrm{d}$

$\rightarrow \mathrm{V}_{\mathrm{w}}=0.606 \mathrm{~m} / \mathrm{s}, \mathrm{V}_{\mathrm{L}}=2.743 \mathrm{~m} / \mathrm{d}$

$\because \mathrm{V}_{\mathrm{w}}=1.002 \mathrm{~m} / \mathrm{s}, \mathrm{V}_{\mathrm{L}}=2.743 \mathrm{~m} / \mathrm{d}$

\# $\mathrm{V}_{\mathrm{w}}=2.398 \mathrm{~m} / \mathrm{s}, \mathrm{V}_{\mathrm{L}}=2.743 \mathrm{~m} / \mathrm{d}$

(c)

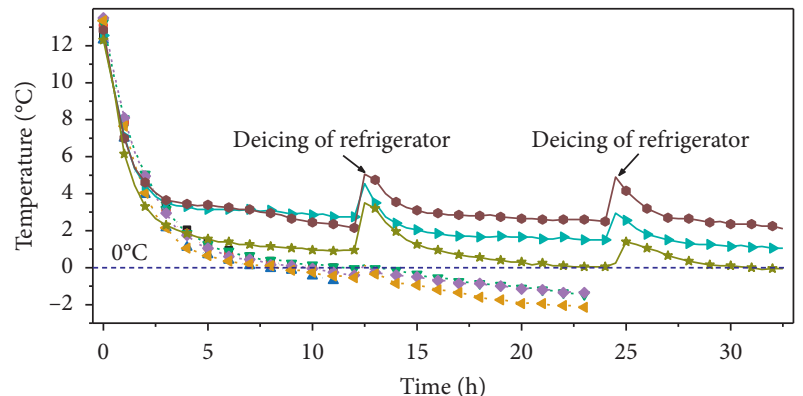

- . $V_{\mathrm{w}}=0.606 \mathrm{~m} / \mathrm{s}, \mathrm{V}_{\mathrm{L}}=0 \mathrm{~m} / \mathrm{d}$

… $\mathrm{V}_{\mathrm{w}}=1.002 \mathrm{~m} / \mathrm{s}, \mathrm{V}_{\mathrm{L}}=0 \mathrm{~m} / \mathrm{d}$

$\ldots \ldots \mathrm{V}_{\mathrm{w}}=2.398 \mathrm{~m} / \mathrm{s}, \mathrm{V}_{\mathrm{L}}=0 \mathrm{~m} / \mathrm{d}$

$\cdots V_{w}=0.606 \mathrm{~m} / \mathrm{s}, \mathrm{V}_{\mathrm{L}}=0.923 \mathrm{~m} / \mathrm{d}$

… $\mathrm{V}_{\mathrm{w}}=1.002 \mathrm{~m} / \mathrm{s}, \mathrm{V}_{\mathrm{L}}=0.923 \mathrm{~m} / \mathrm{d}$

.. $\mathrm{V}_{\mathrm{w}}=2.398 \mathrm{~m} / \mathrm{s}, \mathrm{V}_{\mathrm{L}}=0.923 \mathrm{~m} / \mathrm{d}$

$\rightarrow \mathrm{V}_{\mathrm{w}}=0.606 \mathrm{~m} / \mathrm{s}, \mathrm{V}_{\mathrm{L}}=2.743 \mathrm{~m} / \mathrm{d}$

$\because \mathrm{V}_{\mathrm{w}}=1.002 \mathrm{~m} / \mathrm{s}, \mathrm{V}_{\mathrm{L}}=2.743 \mathrm{~m} / \mathrm{d}$

\# $\mathrm{V}_{\mathrm{w}}=2.398 \mathrm{~m} / \mathrm{s}, \mathrm{V}_{\mathrm{L}}=2.743 \mathrm{~m} / \mathrm{d}$

(d)

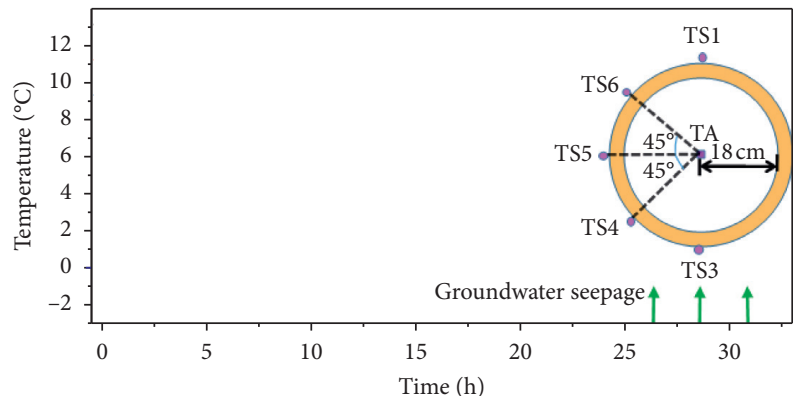

- . $\mathrm{V}_{\mathrm{w}}=0.606 \mathrm{~m} / \mathrm{s}, \mathrm{V}_{\mathrm{L}}=0 \mathrm{~m} / \mathrm{d}$

‥ $\mathrm{V}_{\mathrm{w}}^{\mathrm{w}}=1.002 \mathrm{~m} / \mathrm{s}, \mathrm{V}_{\mathrm{L}}=0 \mathrm{~m} / \mathrm{d}$

… $V_{\mathrm{w}}=2.398 \mathrm{~m} / \mathrm{s}, \mathrm{V}_{\mathrm{L}}=0 \mathrm{~m} / \mathrm{d}$

$\ldots \mathrm{V}_{\mathrm{w}}=0.606 \mathrm{~m} / \mathrm{s}, \mathrm{V}_{\mathrm{L}}=0.923 \mathrm{~m} / \mathrm{d}$

‥ $\mathrm{V}_{\mathrm{w}}=1.002 \mathrm{~m} / \mathrm{s}, \mathrm{V}_{\mathrm{L}}=0.923 \mathrm{~m} / \mathrm{d}$

… $V_{w}=2.398 \mathrm{~m} / \mathrm{s}, V_{\mathrm{L}}=0.923 \mathrm{~m} / \mathrm{d}$

$\rightarrow \mathrm{V}_{\mathrm{w}}=0.606 \mathrm{~m} / \mathrm{s}, \mathrm{V}_{\mathrm{L}}=2.743 \mathrm{~m} / \mathrm{d}$

$\because \mathrm{V}_{\mathrm{w}}=1.002 \mathrm{~m} / \mathrm{s}, \mathrm{V}_{\mathrm{L}}=2.743 \mathrm{~m} / \mathrm{d}$

\# $\mathrm{V}_{\mathrm{w}}=2.398 \mathrm{~m} / \mathrm{s}, \mathrm{V}_{\mathrm{L}}=2.743 \mathrm{~m} / \mathrm{d}$

$\cdots \mathrm{V}_{\mathrm{w}}=0.606 \mathrm{~m} / \mathrm{s}, \mathrm{V}_{\mathrm{L}}=0 \mathrm{~m} / \mathrm{d}$

$\cdots \quad \mathrm{V}_{\mathrm{w}}=1.002 \mathrm{~m} / \mathrm{s}, \mathrm{V}_{\mathrm{L}}=0 \mathrm{~m} / \mathrm{d}$

… $V_{\mathrm{w}}=2.398 \mathrm{~m} / \mathrm{s}, \mathrm{V}_{\mathrm{L}}=0 \mathrm{~m} / \mathrm{d}$

… $V_{w}=0.606 \mathrm{~m} / \mathrm{s}, V_{L}=0.923 \mathrm{~m} / \mathrm{d}$

$\therefore \mathrm{V}_{\mathrm{w}}=1.002 \mathrm{~m} / \mathrm{s}, \mathrm{V}_{\mathrm{L}}=0.923 \mathrm{~m} / \mathrm{d}$

$\therefore 4 V_{\mathrm{w}}=2.398 \mathrm{~m} / \mathrm{s}, \mathrm{V}_{\mathrm{L}}=0.923 \mathrm{~m} / \mathrm{d}$

$\rightarrow \mathrm{V}_{\mathrm{w}}=0.606 \mathrm{~m} / \mathrm{s}, \mathrm{V}_{\mathrm{L}}=2.743 \mathrm{~m} / \mathrm{d}$

$\longrightarrow \mathrm{V}_{\mathrm{w}}=1.002 \mathrm{~m} / \mathrm{s}, \mathrm{V}_{\mathrm{L}}=2.743 \mathrm{~m} / \mathrm{d}$

$\rightarrow \mathrm{V}_{\mathrm{w}}^{\mathrm{w}}=2.398 \mathrm{~m} / \mathrm{s}, \mathrm{V}_{\mathrm{L}}=2.743 \mathrm{~m} / \mathrm{d}$

(e)

FIGURE 8: Variations in the temperature at the interface between the lining and the surrounding rock: (a) TS1, (b) TS3, (c) TS4, (d) TS5, and (e) TS6. 

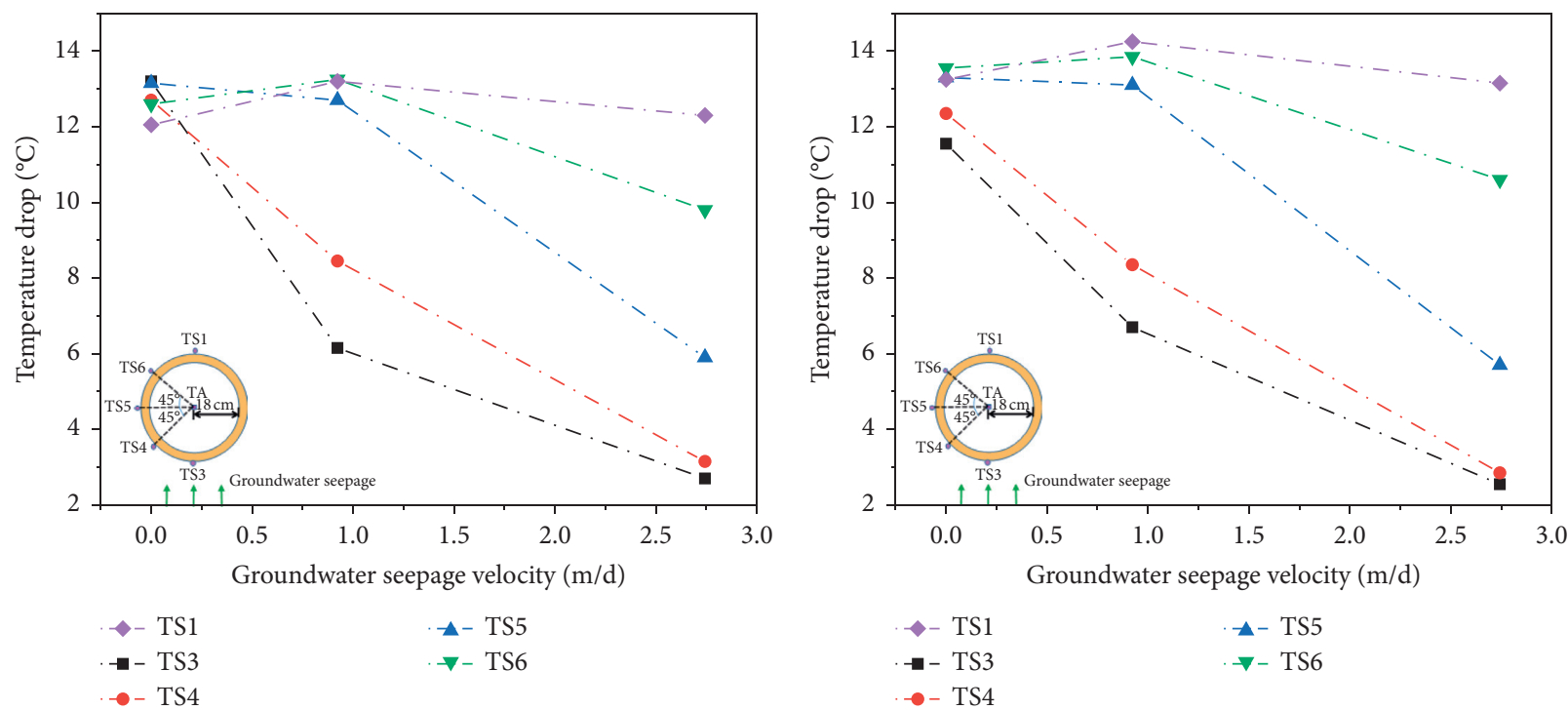

(a)

(b)

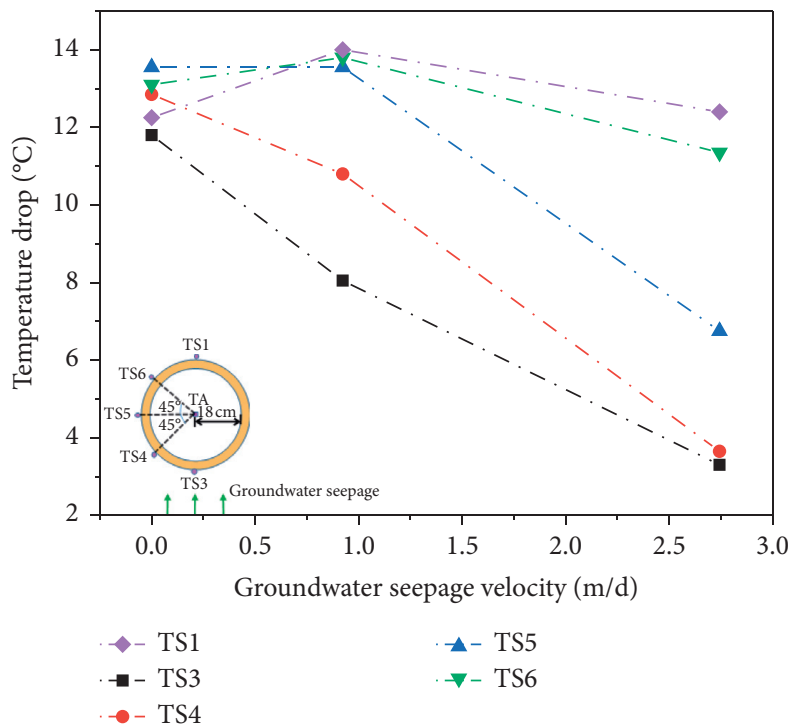

(c)

FigURE 9: Variations in the surrounding rock temperature drop at different groundwater seepage velocities after $11.5 \mathrm{~h}$ of cooling. Average wind speed of (a) $0.606 \mathrm{~m} / \mathrm{s}$, (b) $1.002 \mathrm{~m} / \mathrm{s}$, and (c) $2.398 \mathrm{~m} / \mathrm{s}$.

cold region tunnels suffer tunnel lining leakage and road icing. The results of the model test reveal the cause of tunnel lining leakage and road icing. To avoid tunnel leakage in cold region tunnels, a thermal insulation layer should be properly designed and a heating device should be installed in its longitudinal drainage pipe when the groundwater seepage velocity is low. When the groundwater seepage velocity is $2.743 \mathrm{~m} / \mathrm{d}$, the monitoring point at TS6 freezes but the monitoring points at TS3 and TS5 do not. Furthermore, their temperatures do not decrease significantly as cooling time increases. Therefore, the tunnel has good antifreezing capability when the groundwater seepage velocity is high. This good antifreezing capability should be fully utilized. Furthermore, the foot of the tunnel drainage system should be strengthened against freezing via an insulation layer and heating device.

The above analysis demonstrates that cold region tunnels have an antifreezing capability that is mainly related to the frost heaving of the surrounding rock and the groundwater seepage 


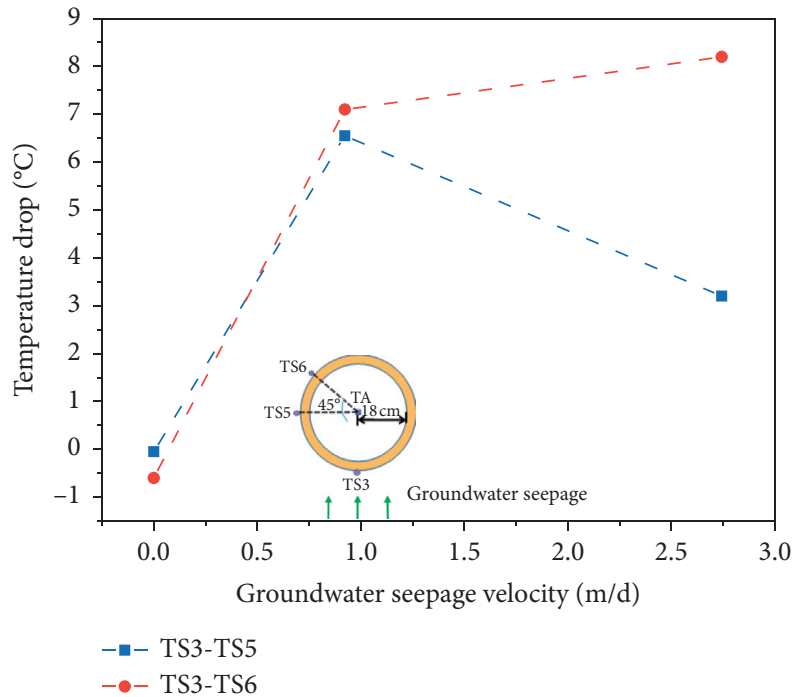

(a)

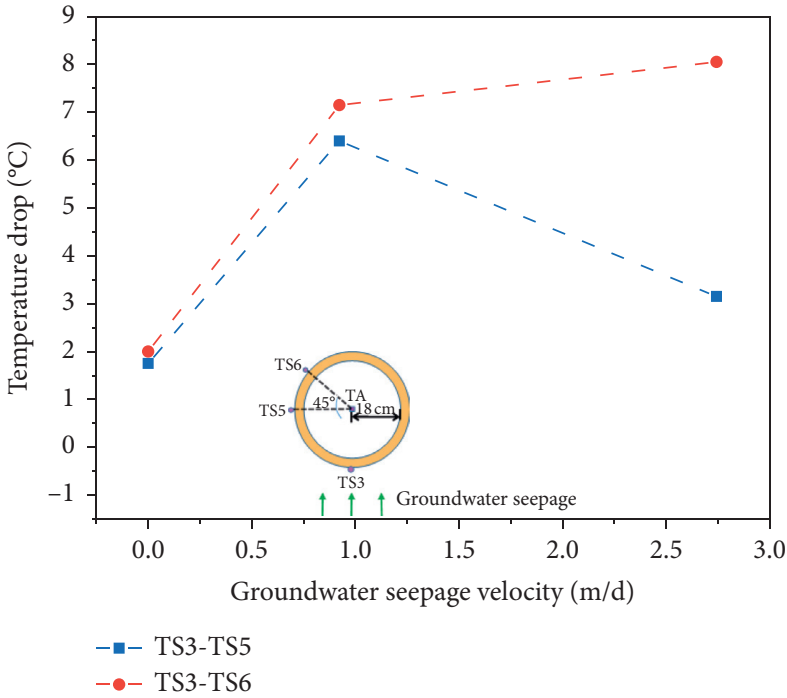

(b)

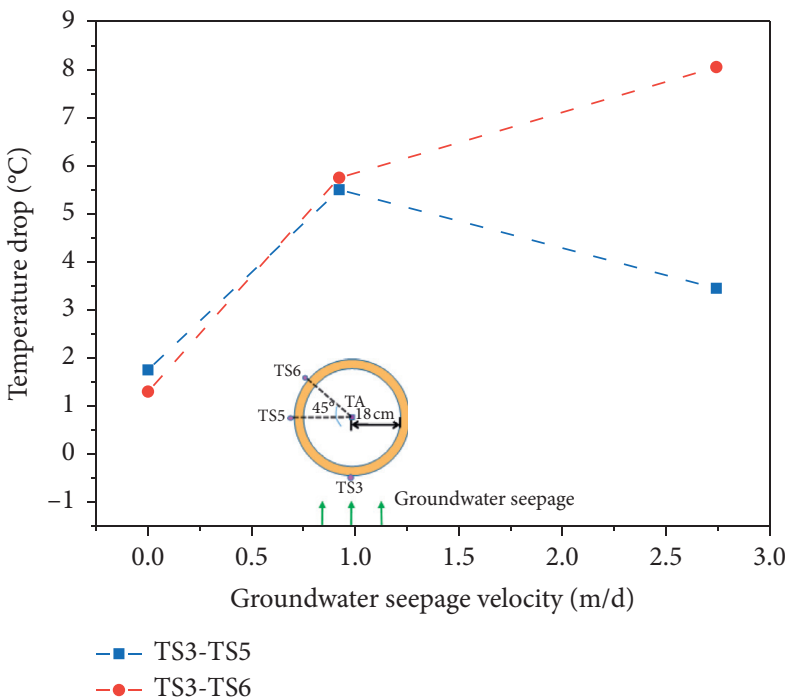

(c)

FIGURE 10: Relationships between the temperature differences at TS5, TS6, and TS3 and groundwater seepage velocity. Average wind speed of (a) $0.606 \mathrm{~m} / \mathrm{s}$, (b) $1.002 \mathrm{~m} / \mathrm{s}$, and (c) $2.398 \mathrm{~m} / \mathrm{s}$.

velocity. This antifreezing capability should be fully utilized in the antifreezing design of cold region tunnels.

\section{Conclusions}

A systematic study on the temperature field of cold region tunnels is presented in which a model test that considers the coupling effects of groundwater seepage and tunnel ventilation is conducted. The effects of groundwater seepage on the air temperature in the tunnel, the surrounding rock temperature, the temperature at the interface between the lining and surrounding rock, and the freezing damage of the tunnel in cold regions are studied. The following four main conclusions are drawn.

First, groundwater seepage has a significant effect on the air temperature in the tunnel. The higher the groundwater seepage velocity, the higher the air temperature in the tunnel. Groundwater seepage has a significant influence on the thickness and length of the tunnel insulation layer in cold regions. The thickness and length of the tunnel insulation layer can decrease under groundwater seepage.

Second, groundwater seepage and tunnel ventilation have a coupling effect on the surrounding rock temperature. Higher groundwater seepage velocity and lower wind speed lead to higher surrounding rock temperature. The influence of groundwater seepage and tunnel ventilation on the surrounding rock temperature field is related to the depth of the surrounding rock.

Third, groundwater seepage leads to an uneven temperature distribution at the interface between the lining and surrounding rock. The tunnel ventilation further enhances this uneven temperature distribution. The groundwater 
seepage and tunnel ventilation have a coupling effect on the interface temperature. This coupling effect is related to the interface location. The influence of the groundwater seepage velocity on the interface temperature has a spatial difference. The shape and size of the cross section of the tunnel have a significant influence on the interface temperature under groundwater seepage.

Fourth, cold region tunnels have an antifreezing capability that is mainly related to the frost heaving of the surrounding rock and the groundwater seepage velocity. The antifreezing capability of the tunnel should be fully utilized in the antifreezing design of cold region tunnels.

\section{Data Availability}

The data used to support the findings of this study are available from the corresponding author upon request.

\section{Conflicts of Interest}

The authors declare that they have no conflicts of interest.

\section{Acknowledgments}

This study was supported by the Key Laboratory of Geotechnical and Underground Engineering of Ministry of Education, Tongji University (No. KLE-TJGE-B1605), the Key Laboratory of Rock Mechanics and Geohazards of Zhejiang Province (No. ZJRM-2018-Y-01), and the Sichuan Science and Technology Program (No. 2018GZ0359).

\section{References}

[1] S. Li, M. Zhang, W. Pei, and Y. Lai, "Experimental and numerical simulations on heat-water-mechanics interaction mechanism in a freezing soil," Applied Thermal Engineering, vol. 132, pp. 209-220, 2018.

[2] S. Li, M. Zhang, Y. Tian, W. Pei, and H. Zhong, "Experimental and numerical investigations on frost damage mechanism of a canal in cold regions," Cold Regions Science and Technology, vol. 116, pp. 1-11, 2015.

[3] S. Shen, C. Xia, J. Huang, and Y. Li, "Influence of seasonal melt layer depth on the stability of surrounding rock in permafrost regions based on the measurement," Natural Hazards, vol. 75, no. 3, pp. 2545-2557, 2015.

[4] K.-J. Jun, Y.-C. Hwang, and C.-Y. Yune, "Field measurement of temperature inside tunnel in winter in Gangwon, Korea," Cold Regions Science and Technology, vol. 143, pp. 32-42, 2017.

[5] Q. Ma, X. Luo, Y. Lai, F. Niu, and J. Gao, "Numerical investigation on thermal insulation layer of a tunnel in seasonally frozen regions," Applied Thermal Engineering, vol. 138, pp. 280-291, 2018.

[6] X. Zhao, X. Yang, H. Zhang, H. Lai, and X. Wang, "An analytical solution for frost heave force by the multifactor of coupled heat and moisture transfer in cold-region tunnels," Cold Regions Science and Technology, vol. 175, 2020.

[7] Y. M. Lai, S. Y. Liu, Z. W. Wu, and W. Yu, "Approximate analytical solution for temperature fields in cold regions circular tunnels," Cold Regions Science and Technology, vol. 34, no. 1, pp. 43-49, 2002.

[8] G. Zhang, C. Xia, M. Sun, Y. Zou, and S. Xiao, "A new model and analytical solution for the heat conduction of tunnel lining ground heat exchangers," Cold Regions Science and Technology, vol. 88, pp. 59-66, 2013.

[9] Y. M. Lai, Z. W. Wu, Y. L. Zhu, and L. N. Zhu, "Nonlinear analysis for the coupled problem of temperature, seepage and stress fields in cold-region tunnels," Tunnelling and Underground Space Technology, vol. 13, no. 4, pp. 435-440, 1998.

[10] X. Zhang, J. Xiao, Y. Zhang et al., "Study of the function of the insulation layer for treating water leakage in permafrost tunnels," Applied Thermal Engineering, vol. 27, no. 2-3, pp. 637-645, 2007.

[11] X. Zhang, Y. Lai, W. Yu, and S. Zhang, "Non-linear analysis for the freezing-thawing situation of the rock surrounding the tunnel in cold regions under the conditions of different construction seasons, initial temperatures and insulations," Tunnelling and Underground Space Technology, vol. 17, no. 3, pp. 315-325, 2002.

[12] X. Zhang, Y. Lai, W. Yu, and Y. Wu, "Forecast analysis for the re-frozen of Feng Huoshan permafrost tunnel on Qing-Zang railway," Tunnelling and Underground Space Technology, vol. 19, no. 1, pp. 45-56, 2004.

[13] X. Tan, W. Chen, H. Tian, and J. Cao, "Water flow and heat transport including ice/water phase change in porous media: numerical simulation and application," Cold Regions Science and Technology, vol. 68, no. 1-2, pp. 74-84, 2011.

[14] X. Tan, W. Chen, G. Wu, and J. Yang, "Numerical simulations of heat transfer with ice-water phase change occurring in porous media and application to a cold-region tunnel," Tunnelling and Underground Space Technology, vol. 38, pp. 170-179, 2013.

[15] X. Tan, W. Chen, D. Yang et al., "Study on the influence of airflow on the temperature of the surrounding rock in a cold region tunnel and its application to insulation layer design," Applied Thermal Engineering, vol. 67, no. 1-2, pp. 320-334, 2014.

[16] S. Li, F. Niu, Y. Lai, W. Pei, and W. Yu, "Optimal design of thermal insulation layer of a tunnel in permafrost regions based on coupled heat-water simulation," Applied Thermal Engineering, vol. 110, pp. 1264-1273, 2017.

[17] Q. Yan, B. Li, Y. Zhang, J. Yan, and C. Zhang, "Numerical investigation of heat-insulating layers in a cold region tunnel, taking into account airflow and heat transfer," Applied Sciences, vol. 7, no. 7, p. 679, 2017.

[18] Q. Feng, B.-S. Jiang, Q. Zhang, and G. Wang, "Reliability research on the 5-cm-thick insulation layer used in the Yuximolegai tunnel based on a physical model test," Cold Regions Science and Technology, vol. 124, pp. 54-66, 2016.

[19] X. Zhang, Z. Zhou, J. Li, Y. Zhou, and F. Han, "A physical model experiment for investigating into temperature redistribution in surrounding rock of permafrost tunnel," Cold Regions Science and Technology, vol. 151, pp. 47-52, 2018.

[20] Y. Zeng, K. Liu, X. Zhou, and L. Fan, "Tunnel temperature fields analysis under the couple effect of convection-conduction in cold regions," Applied Thermal Engineering, vol. 120, pp. 378-392, 2017.

[21] L. Liu, Z. Li, X. Liu, and Y. Li, "Frost front research of a coldregion tunnel considering ventilation based on a physical model test," Tunnelling and Underground Space Technology, vol. 77, pp. 261-279, 2018.

[22] G. Zhang, Y. Guo, Y. Zhou et al., "Experimental study on the thermal performance of tunnel lining GHE under groundwater flow," Applied Thermal Engineering, vol. 106, pp. 784795, 2016.

[23] G. Zhang, S. Liu, X. Zhao et al., "The coupling effect of ventilation and groundwater flow on the thermal performance 
of tunnel lining GHEs," Applied Thermal Engineering, vol. 112, pp. 595-605, 2017.

[24] Q. Hu, R. Shi, Y. Hu et al., "Method to evaluate the safety of tunnels through steeply inclined strata in cold regions based on the sidewall frost heave model," Journal of Performance of Constructed Facilities, vol. 32, 2018.

[25] H. Cai, P. Li, and Z. Wu, "Model test of liquid nitrogen freezing-temperature field of improved plastic freezing pipe," Journal of Cold Regions Engineering, vol. 34, no. 1, 2020.

[26] S. E. A. Gehlin and G. Hellström, "Influence on thermal response test by groundwater flow in vertical fractures in hard rock," Renewable Energy, vol. 28, no. 14, pp. 2221-2238, 2003. 